\title{
PROSES PERBAIKAN PLATE HEAT EXCHANGER TIPE M15 DI PT. JANATA MARINA INDAH (JMI) SEMARANG
}

\author{
*Adi Kurniawan Yusim, Budi Utomo, Suharto dan Hartono \\ Prodi Teknologi Rekayasa Konstruksi Perkapalan Sekolah Vokasi Undip \\ *adi_ky@undip.ac.id
}

\begin{abstract}
Abstrak
Heat exchanger di kapal kebanyakan berbentuk shell and tube. Bentuk yang lain adalah plate heat exchanger (PHE). Kelebihan PHE adalah mempunyai permukaan perpindahan yang sangat besar pada volume alat yang kecil. Pemilihan material gasket yang sesuai pada PHE merupakan hal yang sangat penting. Hal ini bertujuan untuk umur pemakaian PHE yang lama. Penelitian telah dilakukan di galangan kapal PT. JMI Semarang untuk mengetahui letak dan penyebab kebocoran pelat dari PHE. Pengamatan dan perbaikan PHE dilakukan saat kapal naik dock di galangan tersebut. Perbaikan dilakukan secara langsung berupa data operasional dan manual book PHE tipe M15.
\end{abstract}

Kata Kunci: Perbaikan, Plate Heat Exchanger, Gasket.

\begin{abstract}
Abstrct
Most of the heat exchangers on board are in the form of shell and tube. Another form is the plate heat exchanger (PHE). The advantage of PHE is that it has a very large displacement surface at a small volume of tools. Selection of suitable gasket material for PHE is very important. It is intended for a long service life of PHE. The research has been conducted at the shipyard of PT. JMI Semarang to find out the location and cause of plate leakage from PHE. PHE observations and improvements are carried out when the ship is docked at the shipyard. Repairs were made directly in the form of operational data and manual book PHE M15 type.
\end{abstract}

Keyword: Repair, Plate Heat Exchanger, Gaskets.

\section{PENDAHULAN}

Plate Heat Exchangers (PHE) adalah suatu tipe Heat Exchanger (HE) yang menggunakan plat sebagai tempat perpindahan panas di antara dua fluida. Penukar kalor ini merupakan penukar kalor yang sangat kompak karena memiliki kekompakan yang sangat tinggi [1]. PHE terdiri dari plat-plat yang sudah dibentuk dan ditumpuktumpuk sedemikian rupa sehingga alur aliran untuk suatu fluida akan terpisahkan oleh plat itu sendiri terhadap aliran fluida satunya serta dipisahkan dengan gasket. Jadi, kedua fluida yang saling dipertukarkan energinya tidak saling bercampur. Suatu gasket dari suatu PHE berfungsi untuk menghindari bercampurnya fluida panas dengan fluida dingin. gasket diapit diantara pelat dan menyegel pelat disekeliling tepi pelat tersebut. Plat dari HE ini noramalnya mempunyai ketebalan berkisar 0,5 hingga $3 \mathrm{~mm}$.

Suatu alat penukar kalor sangat berpengaruh dalam keberhasilan dalam keseluruhan rangkaian proses, karena dengan adanya kegagalan operasi alat ini baik kegagalan mekanik maupun operasional maka dapat menyebabkan berhentinya operasi unit. Oleh karena itu sebuah alat penukar kalor (Heat Exchanger) dituntut untuk memiliki kinerja yang baik agar dapat diperoleh hasil yang maksimal serta dapat menunjang penuh terhadap suatu unit yang sedang beroperasi [1].

Pada motor diesel yang digunakan di kapal, alat pendingin air tawar biasanya berbentuk cangkang dan tabung (shell and tube) dengan air laut sebagai media pendinginnya [2]. Tipe PHE M15 (lihat Gambar 1) diaplikasikan 
pada sistem pendingin kapal ini. Kedua tipe HE ini merupakan klasifikasi berdasarkan desain konstruksi. Pengklasifikasian heat exchanger berdasarkan desain konstruksinya, menjadi pengklasifikasian yang paling utama dan banyak jenisnya. Pada saat reparasi di PT. Janata Marina Indah (PT. JMI), kapal ini mengalami kebocoran pada sistem pendinginnya. Sehingga memerlukan penanganan khusus. Awalnya, proses penanganan kebocoran PHE ini berjalan cukup sulit. Hal tersebut dikarenakan tipe sistem pendingin PHE jarang ditemui di kapal.

Sangat jarang ditemui jurnal yang membahas PHE yang diaplikasikan di kapal dan proses perbaikannya. Akhirnya Penulis mendapatkan jurnal tentang studi PHE pada Pembangkit Listrik Tenaga Gas Uap (PLTGU) [1]. Analisis kegagalan material (kebocoran) pada pelat PHE yang dioperasikan di pembangkit listrik. Kebocoran pelat diakibatkan oleh korosi [3]. Dari penelitian dan publikasi ini diharapkan banyak pihak terbantu dalam proses reparasi dalam sistem pendingin jenis PHE dan teraplikasi pada kapal.

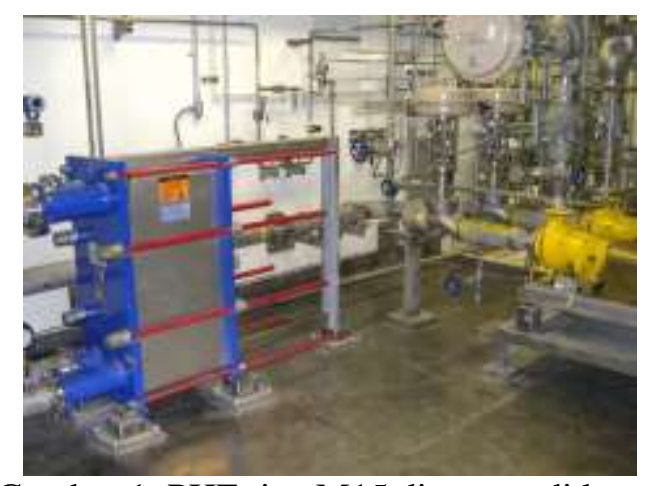

Gambar 1. PHE tipe M15 dipasang di kapal

\section{METODE}

\subsection{Spesifikasi Teknik PHE}

PHE tipe M15 banyak diaplikasikan di industri farmasi, kimia, pembangkit listrik, makanan dan minuman, manufaktur, dan transportasi (kapal) [4]. Data desain secara mekanik yang meliputi spesifik teknik dari PHE dan merupakan dimensi ukuran keseluruhannya serta jenis material yang digunakan pada tipe M15. Spesifikasi teknik PHE tipe M15 bisa dilihat pada Gambar 2 dan Tabel 1.
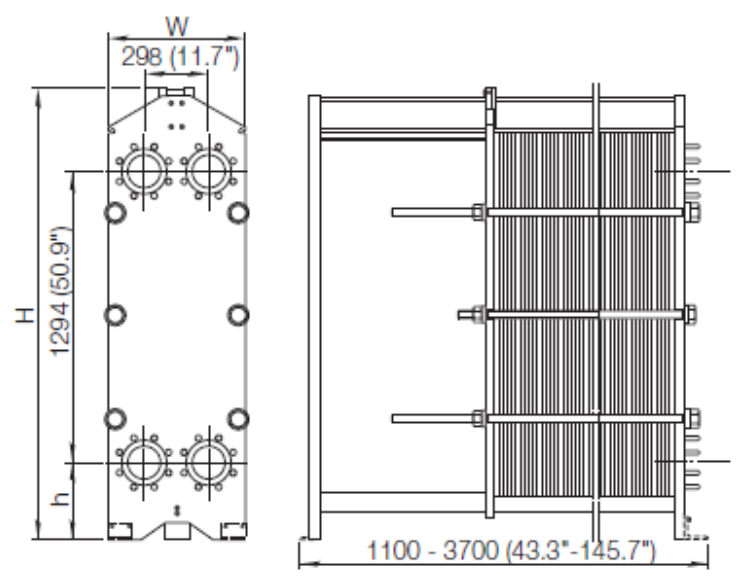

Gambar 2. Spesifikasi Teknik PHE [3]

Tabel 1. Datasheet Spesifikasi Teknik dari PHE tipe M15 [4]

\begin{tabular}{ll}
\hline Material plat & Stainless steel: Alloy 304, Alloy 316, Alloy \\
& C276, Alloy 254, SMO, Titanium \\
\hline Tebal plat & $16,3 \mathrm{~m}$ \\
Jumlah Pass & One/single pass \\
Heat Transfer Area $\left(\mathrm{m}^{2}\right)$ & 390 \\
\hline
\end{tabular}

copyright is published under Lisensi Creative Commons Atribusi 4.0 Internasional. 


\begin{tabular}{ll}
\hline Liquid flow rate $(\mathrm{kg} / \mathrm{s})$ & 80 \\
$\mathrm{~h}(\mathrm{~m})$ & 0,275 \\
$\mathrm{H}(\mathrm{m})$ & 1,941 \\
$\mathrm{~W}(\mathrm{~m})$ & 0,610 \\
\hline
\end{tabular}

\subsection{Perbaikan PHE tipe M15}

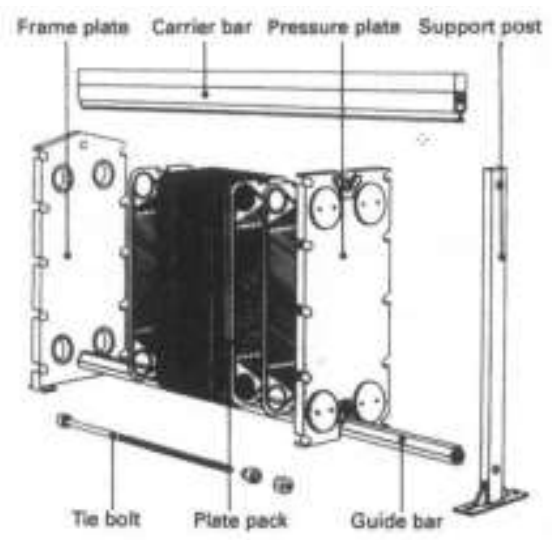

Gambar 3. Bagian-bagian dari PHE [6]

PHE dibuat dari rakitan pelat logam identik yang ditekan secara bersamaan. Pelat tersebut memiliki pola gelombang secara horizontal. Setiap ruang kerja pelat dilindungi oleh sambungan karet nitril (gasket). Pelat yang disangga di bawah dan digantung di bagian atas oleh rel logam dapat dipindahkan, disatukan pada pelat ujung dengan menjepit baut pengikat. Bagian-bagian dari PHE dapat dilihat pada Gambar 3. Pembongkaran ini bertujuan untuk menemukan letak kerusakan/kebocoran dari komponen PHE.

Dalam proses perbaikan PHE perlu dilaksanakan secara teliti dan hati-hati supaya perbaikan PHE yang dikerjakan bisa berhasil secara maksimal dalam jangka waktu yang diharapkan. Adapun tahap-tahap yang dilakukan dalam proses perbaikan PHE yang sudah dilakasanakan di PT. JMI adalah sebagai berikut:

\subsubsection{Tahap Pembongkaran}

Dalam tahap pembongkaran PHE, langkah-langkah yang dikerjakan harus secara berurutan, meliputi:

a. Pengeringan semua cairan yang masih ada di dalam PHE.

b. Pemeriksaan dan pemberihan sliding PHE.

c. Penandaan (marking) pada sisi luar channel plates PHE untuk memudahkan urutan saat pemasangan.

d. Pengukuran jarak frame plate sebelum dibuka untuk acuan pengikatan atau pengencangan saat pemasangan.

e. Pembukaan channel plates dan diposisikan pada tempat yang aman.

\subsubsection{Tahap Pembersihan dan Pengecekan Channel Plates}

Tahap ini dilaksanakan setelah channel plates PHE dibuka untuk memastikan channel plates masih bisa dipakai atau tidak, dengan cara:

a. Pembersihan channel plates PHE dengan menggunakan cairan yang sesuai dengan kondisi channel plates dan direkomendasikan oleh maker.

b. Pengecekan channel plates PHE, dilakukan untuk mengetahui kondisi kelayakannya. Adapun prosesnya meliputi:

1). Pengecekan secara visual, untuk mengetahui kondisi channel plates terjadi deformasi atau tidak.

2). Pengecekan dengan dye penetrant (color check), untuk mengetahui keadaan retak pada channel plates.

3). Pengecekan dengan lampu sorot, untuk mengetahui adanya lubang pada channel plates.

Apabila dari hasil pengecekan ditemukan deformasi, keretakan, dan lubang yang tidak memungkinkan untuk diperbaiki maka channel plates harus diganti baru. 


\subsubsection{Tahap Penggantian Seal Channel Plates}

Setelah dilaksanakan pembersihan dan pengecekan channel plates, kemudian dilakukan penggantian seal dengan urutan pekerjaan sebagai berikut:

a. Buka seal lama dari kedudukannya.

b. Pastikan seluruh permukaan dudukan seal kering dan bersih.

c. Pastikan penjepit (chip) seal bisa terpasang pada dudukan.

\subsubsection{Tahap Pemasangan Channel Plates}

Tahapan berikutnya adalah pemasangan channel plates dengan urutan sebagai berikut:

a. Pengecekan seluruh permukaan seal dalam kondisi bersih.

b. Pastikan drat, mur, dan baut pengikat PHE dalam kondisi bersih dengan menggunakan sikat yang diolesi grease serta pastikan mur bisa berputar lancar pada bautnya.

c. Pengecekan kondisi semua seal sudah terpasang dengan benar pada channel plates.

d. Pemasangan channel plates sesuai urutan (marking).

e. Pengikatan atau pengencangan frame plates dengan mur dan baut secara bertahap serta jarak sesuai dengan ukuran semula.

\subsubsection{Tahap Pressure Test PHE}

Untuk memastikan perbaikan PHE terlaksana dengan baik dan benar maka dilakukan pressure test dengan tekanan sesuai yang tertera pada name plate PHE dengan menggunakan test pump pada sistem PHE.

\section{HASIL DAN PEMBAHASAN}

Berdasarkan hasil pengamatan dan penyelesaian di galangan menunjukkan bahwa PHE memerlukan ketelitian dalam proses menemukan kebocoran pada gasket. Pengaturan segel ganda disediakan pada setiap titik percabangan dengan lubang pembuangan (drain hole) untuk mendeteksi kebocoran dan mencegah pencampuran fluida, dapat dilihat pada Gambar 4.

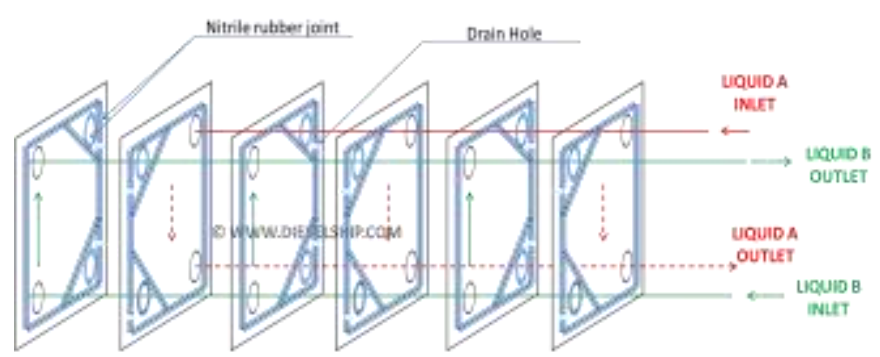

Gambar 4. Lubang Pembuangan pada Gasket [5]

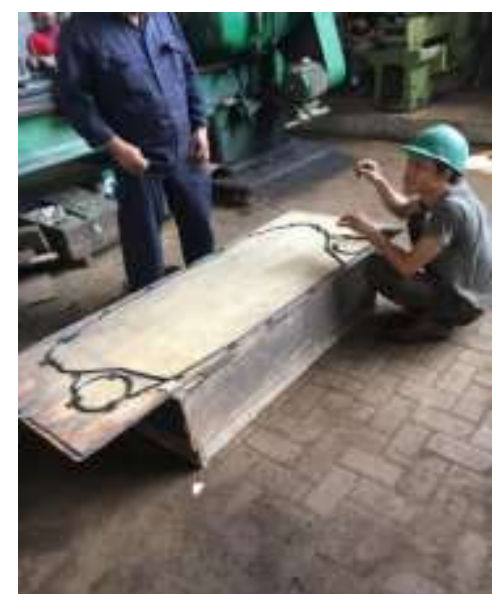

Gambar 5. Proses Perbaikan PHE di PT. JMI Semarang copyright is published under Lisensi Creative Commons Atribusi 4.0 Internasional. 
Gasket PHE merupakan komponen yang paling sering diganti karena setiap pembongkaran PHE sebagian besar gasket sudah tidak dapat digunakan lagi. Gasket mengalami deformasi bentuk. Material gasket harus memiliki ketahanan terhadap fluida yang kontak dan temperatur kerja PHE supaya dapat digunakan dalam periode waktu yang relatif lama. Material karet gasket yang sering digunakan adalah EPDM, NBR, Viton, dan Butyl. Proses penggantian gasket dilakukan di darat (galangan) bisa dilihat pada Gambar 5.

\section{KESIMPULAN}

Proses perbaikan PHE tipe M15 di galangan kapal PT. JMI Semarang berlangsung cukup lama. Hal tersebut dikarenakan proses pembongkaran keseluruhan komponen PHE membutuhkan ketelitian untuk menemukan letak gasket yang rusak mengingat jumlah gasket dan pelat yang banyak serta saling berhubungan. Proses perbaikan PHE terlaksana dengan baik dan benar dengan mengikuti prosedur serta urutan yang telah disampaikan pada pembahasan sebelumnya.

\section{UCAPAN TERIMA KASIH}

Penulis mengucapkan terima kasih kepada PT. JMI Semarang yang menjadi tempat penelitian ini.

\section{DAFTAR PUSTAKA}

[1] R. Walikrom, A. Muin and Hermanto, "Studi Kinerja Plate Heat Exchaner pada Sistem Pendingin PLTGU," Turbulen: Jurnal Teknik Mesin, vol. I, no. 1, p. 40 - 47, 2018.

[2] L. Jauhari, "http://bppp-tegal.com/," BPPP Tegal, 03 Desember 2012. [Online]. Available: http://bppptegal.com/v1/index.php?option=com_content \&view=article\&id=228:sistem-pendinginan-motordiesel\&catid=44: artikel\&Itemid=85. [Accessed 05 February 2020].

[3] F. Z. Dong, D. J. S. , Z. B. Zhang, M. Y. C., C. S. Y., K. Niu and L. C. X., "Internal leakage of plate heat exchangers caused by cooperation of pitting, crevice corrosion, and fretting," Engineering Failure Analysis, vol. 96, pp. 340-347, 2019.

[4] A. Laval, "Alfa Laval M15," www.alfalaval.com, Lund, 2016.

[5] A. Laval, "Gasketed plate and frame heat exchangers," Alfa Laval Corporate, Lund, 2019.

[6] D. Ship, "https://dieselship.com/," Diesel Ship, 06 July 2019. [Online]. Available: https://dieselship.com/marine-technical-articles/marine-engineering-knowledge-general/plate-typeheat-exchanger/. [Accessed 09 February 2020]. 